\title{
Conceptions and Feelings of Nurses Working in Emergency Medical Services about their Professional Practice and Training
}

\author{
Evânio Márcio Romanzini ${ }^{1}$ \\ Lisnéia Fabiani Bock ${ }^{2}$
}

\begin{abstract}
This descriptive study with qualitative approach aimed to identify the feelings that result from the practice and training of nurses working in mobile Emergency Medical Services (EMS). Nine nurses were interviewed in September 2007. Bardin's content analysis was used and six categories emerged: "Feelings aroused in the EMS", "Experiences in the daily routine", "nurses' activities in EMS", "Personal and professional preparedness", "Reflecting on the professional training" and "Nurses' perceptions of the EMS". The importance of this study lays in the need for personally, professionally and emotionally prepared nurses and also in the need to acknowledge and value the nursing practice in this service. The results revealed that nurses working in EMS feel secure, prepared and motivated to work and they also experience diverse feelings such as compassion, gratitude, anger, pity, sadness and anxiety. Acknowledgment and the possibility of restoring lives motivate them.

Descriptors: Emergency Medical Services; Emergency Nursing; Pacient Care Team; First Care; Emergency Relief.
\end{abstract}

\footnotetext{
${ }^{1}$ RN, Pronto Atendimento Médico Cruzeiro do Sul, RS, Brazil, and Hospital Geral de Porto Alegre, RS, Brazil. Graduate Student, Cardiology Nursing Graduate Program, Instituto de Cardiologia de Porto Alegre, RS, Brazil. E-mail: maromanzini@yahoo.com.br.

${ }^{2}$ RN, Hospital Moinhos de Vento de Porto Alegre, RS, Brazil. Faculty, Centro Universitário Metodista do Sul - IPA, Brazil. Doctoral Student, Nursing Graduate Program, Universidade Federal de Santa Catarina, SC, Brazil. E-mail: ffabibock@hotmail.com.
}

Corresponding Author:

Lisnéia Fabiani Bock

Centro Universitário Metodista do Sul - IPA

Rua Cel. Joaquim Pedro Salgado, 80

Rio Branco

CEP:90420-060 Porto Alegre, RS, Brasil,

E- mail: ffabibock@hotmail.com 


\title{
Concepções e sentimentos de enfermeiros que atuam no atendimento pré-hospitalar sobre a prática e a formação profissional
}

Este é estudo descritivo, com abordagem qualitativa, e teve como objetivo identificar os sentimentos resultantes da atuação e formação dos enfermeiros do serviço de atendimento pré-hospitalar (APH) móvel de urgência. Foram entrevistados 9 enfermeiros, em setembro de 2007. Utilizou-se a técnica de análise de conteúdo de Bardin, que auxiliou na formação de seis categorias: "sentimentos despertados no APH", "experiências decorrentes no dia a dia do trabalho", "atividades do enfermeiro no APH", "preparo pessoal e profissional", "refletindo sobre a formação profissional" e "percepção do enfermeiro sobre o APH". A importância deste trabalho reside na necessidade de enfermeiros com capacitação pessoal, profissional e emocional, também no reconhecimento e valorização da atuação da enfermagem nesse Serviço. Os resultados revelaram que os enfermeiros do APH se sentem seguros, preparados e motivados para atuar, experimentam diversos sentimentos como compaixão, gratidão, raiva, pena, tristeza, ansiedade, e consideram como motivador o reconhecimento e a possibilidade de restaurar vidas.

Descritores: Serviços Médicos de Emergência; Enfermagem em Emergência; Equipe de Assistência ao Paciente; Primeiros Socorros; Socorro de Urgência.

\section{Conceptos y sentimientos de enfermeros que actúan en la atención pre-hospitalaria sobre la práctica y la información profesional}

\begin{abstract}
Este es estudio descriptivo, con abordaje cualitativo que tuvo como objetivo identificar los sentimientos resultantes de la actuación y formación de los enfermeros del servicio de atención pre-hospitalaria (APH) móvil de emergencia. Fueron entrevistados 9 enfermeros, en septiembre de 2007. Se utilizó la técnica de análisis de contenido de Bardin, que auxilió en la formación de seis categorías: "sentimientos despertados en el APH", "experiencias provenientes en el día a día del trabajo", "actividades del enfermero en el $\mathrm{APH}^{\prime}$, "preparación personal y profesional", "reflexionando sobre la formación profesional", y, "percepción del enfermero sobre el APH". La importancia de este trabajo reside en la necesidad de contar con enfermeros con capacitación personal, profesional y emocional, también obtener el reconocimiento y valorización de la actuación de la enfermería en ese Servicio. Los resultados revelaron que los enfermeros del APH se sienten seguros, preparados y motivados para actuar, experimentan diversos sentimientos como compasión, gratitud, rabia, pena, tristeza, ansiedad, y consideran como incentivos el reconocimiento y la posibilidad de restaurar vidas.
\end{abstract}

Descriptores: Servicios Médicos de Urgencia; Enfermería de Urgencia; Grupo de Atención al Paciente; Primeros Auxilios; Socorro de Urgencia.

\section{Introduction}

Throughout history, nursing has had a marked participation in the delivery of emergency care and the rescue of the sick and injured in wars. Another undeclared war in modern society "that of violent causes, cardiovascular, respiratory and metabolic diseases" is mainly responsible for the mortality caused by urgent/ emergent situations ${ }^{(1-3)}$.
Emergency medical services (EMS) emerged in Brazil in the city of Rio de Janeiro in 1893 as an intervention of the state through the Health and Public Security Sector. It was a measure to provide early and rapid care with appropriate transportation to an emergency ward in order to limit the risks, complications and sequelae of victims and increase their survival. In Brazil there are currently 
two models of EMS: SAMU, which is a mobile urgent care service of French origin composed of emergency field physician specialists and the American model that includes technicians in medical emergencies at the basic and intermediate levels and paramedics ${ }^{(2)}$.

The SAMU in Porto Alegre was implemented through an agreement with France in 1995 and uses a mixed model in which the regulator physician decides whether to send a basic unit composed of a nursing technician or advanced support with a nurse and physician, or even a rapid response vehicle with a physician to support the basic unit ${ }^{(2-4)}$.

EMS includes the initial actions performed in a short period of time by the rescue team at the site where the event occurs, whether it is traumatic, clinical or physic. The safe removal of victims with life support to a healthcare facility of excellence has currently become essential. Because nurses are inserted into this scenario, they face various challenges related to the operationalization of the service, as well as their background and professional training(3,5-6).

The existence of gaps in nurses' education coupled with difficulties presented by nursing scholars in relation to theory and practice in situations that involve human fragility, personal preparedness, the legal profile necessary to work in EMS and the need for qualified professionals for the work, motivated the authors of this study ${ }^{(6-7)}$.

The importance of this study lays in the possibility of enlarging knowledge concerning the role nurses have played in EMS, analyzing the feelings that arise in the practice of this service and nurses' attributes, competencies, responsibilities and contexts, to support nursing as a component in the multi-professional decision-making process related to issues in EMS.

As a way to acknowledge the nurses' feelings related to the practice and training required for the work in EMS, the following questions were posed: "what are the feelings of nurses who work in EMS in relation to their practice and professional training? And what are the experiences that emerge from this practice?"

Based on these concerns, this study aimed to identify the feelings of nurses working in EMS related to their practice and professional training.

\section{Method}

This qualitative and descriptive study was carried out with nurses working in the public EMS, SAMU in Porto Alegre, RS, Brazil who agreed to participate in the study.
Nine $(56.2 \%)$ of the nurses working in the service were interviewed; the majority were female $(88.8 \%)$; ages between 41 and 45 years (33.3\%); having 12 to 16 years since graduation $(44.4 \%) ; 66.7 \%$ were specialists: $22.2 \%$ in the urgent and emergency fields, $22.2 \%$ were masters and $11.1 \%$ were doctors. The majority had worked for five to seven years in SAMU (66.6\%).

Nurses who were not active in September 2007 or had not yet worked with emergency services were excluded from the study. Data were obtained through a recorded interview following a semi-structured questionnaire developed by the researchers with five questions addressing the practice and professional training and situations experienced in the daily routine of EMS.

The study was initiated after the Ethics Research Committee at the Secretary of Health in Porto Alegre approved the project and the Director of the Emergency Hospital and the SAMU's Coordination leadership authorized it. Interviews were individually carried out on random dates according to the participants' availability, in a calm environment at the service's headquarters.

Confidentiality of the participants was ensured through the adoption of pseudonyms used in the communication between teams, for instance: Alpha, Bravo, Charlie, Delta, Eco, Foxtrot, Golf, Hotel and India according to the chronological order of interviews. All participants signed free and informed consent forms and received a copy of the study's instrument according to the article 25 of Resolution 196/1996 of the Brazilian Council of Health.

Bardin's content analysis was used, guided by the assumptions of qualitative research ${ }^{(8)}$. Interviews were fully transcribed, in which the language of subjects was kept, including time for pauses, silence, behavioral aspects and interviewees' body manifestations.

The development of categories for content analysis allowed making relations between the reports, thoughts and the object, because these are involved in each other, making possible the construction of an inter-subjective knowledge $^{(9)}$.

\section{Results and discussion}

Based on the theoretical foundation and significant and reliable data obtained, interpretation and the study's proposed objectives were carried out of which six categories related to the emergency medical service emerged. 


\section{First category: "Feelings aroused in the EMS"}

The first category presents the feelings that arise during and after delivering care and rescuing patients. The feelings are diverse and the violence of some situations, which is always something new for EMS nurses, is emotionally shocking for professionals.

Nurse Bravo - compassion, security in a certain way, personal pride, sometimes, indignation and finally a great satisfaction. Acknowledgment by patients and family members, which is something you don't have in the daily routine of hospitals.

Nurse Charlie - Each scene, each case is different, I've already felt anger, pity [...] sorrow, you experience all feelings that exist and everything you can describe.

Nurse Delta - Anxiety, fear, not knowing what you'll find and then after delivering care you see the results; sometimes, satisfaction, other times, frustration, in fact feelings are very diverse, $[. .$.$] there are moments in which you are dealing with$ situations between the police and fugitives [...] ambiguities emerge, there's no way to escape from this, I may be caring for someone who will possibly be attacking my family in the future.

The reports of the nurses Bravo, Charlie and Delta show the constant concern in delivering care to the victim as a whole, valuing the social context in which the victim is included, which is a essential characteristic of nursing - having empathy for people, seeking to care for them in an integral way, even in emergency situations. This is clearly noted in the various feelings experienced and manifested by EMS nurses.

\section{Second category: "experiences in the daily routine"}

The occurrences in which the EMS team manages to rescue, stabilize and transport the victim with life support to a hospital of excellence are considered positive, even if the victim is already in respiratory arrest or has other severe traumas. Nurses also consider positive demonstrations of gratitude and acknowledgment of people to whom they delivered care to be important.

Negative experiences are related to the constant turnover of team members, insufficient qualifications of physicians and the nursing personnel, beginners, lack of preparedness of people on the streets, occurrences in which there is miscommunication and also when the mobile unit arrives too late to the site, that is, when there is nothing to do and the victim is already dead or is a child.

When care delivery occurs as planned, the team manages to produce integrated work, there are no significant errors and care is properly delivered. Even when the team is not successful in saving the victim's life, the work is considered positive because they managed to do what was supposed to be done in the best possible way.

Nurse Alpha - Ah, I believe that the positive actions are those that recover life $[. .$.$] , oftentimes you don't manage to do it$ [...]. I cared for a girl once who had been stabbed in the tummy ah... she was a call-girl, had exposed viscera [...], was really bad, pale, had lost a lot of blood. After three days she came to thank me and wrote a very touching letter. We had changed her life and she acquired a new perspective on life.

Nurse Bravo - There was a case of a 22 year old guy who was sleeping and wasn't able to turn himself on the bed [...] we took 25 minutes between rescuing him and taking him to the hospital PUC/RS and when we left him there he already had dysphasia, had become mydriatic and pale [...]. Sometime ago he walked into the base to thank us. We're certain that if wasn't for the EMS' immediate action this boy would be paralyzed and unable to communicate.

Nurse Golf - I just got back from an extremely positive experience. We responded to a respiratory arrest case, a 50 year old man had a sudden illness, we took him out of the car and laid him down on the street, we spent 50 minutes resuscitating him and we managed to reverse his condition and the patient is well, is alive here in the Polytrauma.

The presence of a nurse to attend these occurrences makes the team feel safe and calm enough to make decisions. Nurses have initiative and derive satisfaction from helping without measuring efforts, always working on behalf of patients. As a team member, nurses contribute to the performance of interventions and procedures during care aiming to increase the victims chances of survival(10-11)

The reports of Alpha, Bravo and Golf reveal that they feel gratified when they manage to reestablish or preserve the life and integrity of victims. This is a source of personal and professional satisfaction, especially when patients or family members and friends acknowledge their work.

The difficulties indicated by the nurses are due to the organization of the EMS, to the relationships among the teams, unnecessary exposure to risk situations and the relationship with the population.

Nurse Alfa - A negative aspect is when the team is not prepared, the medical team and the nursing team. It happens a lot in the city's service because a lot of new physicians enter the service and it takes a lot to learn the EMS routine.

Nurse Bravo - We were caring for a respiratory arrest on the street, [...] Jand the patient was on the floor and his family member kicked the rescuer, who was performing cardiac massage, in the back [...], every emergency situation in a family 
with a dear one, generates some stress, and people sometimes act in such a way that they can't control.

Nurse Eco - I had a situation in which I had to go into a long alley with an armed policeman, which I couldn't decline because there were people watching. Nobody said that those people were already dead and exposed us knowing that we couldn't do anything. Being unnecessarily exposed is really bad.

Nurse Golf - The first time I had to go into the field was with a 16 years old girl who had committed suicide, so we got to the place and there wasn't anything we could do [...] I felt the team felt out of balance. We couldn't keep the integrity of the team in view of the situation, the father despaired because she killed herself with his gun.

Miscommunication, delays, getting to the event's site too late, a dead victim or when children are involved, are situations that might destabilize the teams. However, these situations enable moments of reflection and awareness, considering that not everything is perfect, there are failures, these situations should serve as lessons for personal and professional growth.

\section{Third category: "nurses' activities in the EMS"}

This category identifies, through the reports of the EMS nurses, their main responsibilities and contributions in the planning, organization and delivery of care.

Nurse Eco - At the headquarters, nurses are responsible for checking the ambulance, are responsible for the material and care during the occurrences [...] and are also responsible for supervising the driver.

Nurse Alpha - The coordinator is the manager, who is also in charge of planning and follow-up. Nurses are directly linked to the mobile ICUs [...] observing the occurrences [...]. It is the nurse who organizes, schedules shifts, checks equipment and material daily that goes through the headquarters.

Nurse Hotel - Managing a team of one hundred and something employees [...] The nurse coordinates his headquarters, contributes to the coordination of nursing in terms of providing suggestions on issues that emerge in the daily routine $[. .$.$] .$

Nurses are essential in the direct care provided to victims, in the technical training of teams, in the development of care protocols and didactic material and supervision of personnel. Nurses enable faster, more organized, calmer and safer care delivery and are considered an anchor for the teams ${ }^{(3-10)}$.

\section{Fourth category: "personal and professional preparedness"}

This category identified how nurses feel in relation to their personal and professional preparedness to work in the EMS, taking into account the recent implementation of the service, nurses' education and their time working in the SAMU in Porto Alegre. Their emotional preparedness to act in stressful situations and under psychological pressure given the service's peculiarities became evident.

Nurse Golf - I had a hard time when I entered the SAMU $[\ldots]$, delivering care on the streets is very different $[. .$.$] , we$ have to deal with the patient, with the population, with risk situations [...]. You have to have more emotional than technical preparedness [...] to deal with situations that push your patience to the limit $[. .$.$] , people who intrude [...] trying to help, we are$ oftentimes attacked.

Nurse Alpha - I had nothing related to prehospital services during my undergraduate program [...] when I came to SAMU [...] I had to learn everything while working in the service itself.

Previous studies indicate that undergraduate programs pay little attention to the training required to work in emergency medical services ${ }^{(6-7,10)}$.

Nurse India - College does not prepare us for prehospital service [...]. I really got here knowing absolutely nothing, I've learned everything while working in the service.

Nurse Bravo - Now I feel extremely secure about everything I do, I have no doubts about the decisions I make.

A study carried out in SAMU in São Paulo analyzed the knowledge necessary for nurses to work in the EMS and the results indicated that the knowledge recommended by the Ministry of Health through regulation N. 2048/02 is basic. This included essential theoretical updates, development of technical abilities, decision-making, readiness, the skill and ability to act under high pressure or with a specific population, which indicates the need for specific programs to train professionals for emergency medical services ${ }^{(12)}$.

\section{Fifth category: "Reflecting on professional training"}

In order to support a discussion about the legal profile required to work in EMS and the nurses' education, we asked them what they felt they lacked in their educational program or what could be done differently during their educational program.

Nurse Alpha - prehospital services were not addressed during my academic training [...]. We are trained to work in the hospital, where everything is more accessible, where there are professionals around and not to work by yourself on the streets [...]. In the course of an emergency, they could include a range of issues and talk a little about this type of care delivery.

Nurse Foxtrot - It wasn't organized as it is now, I graduated 12 years ago and have worked 11 for SAMU, so there should be supervised training in this field, training observations in this field [...]. 
Nurse India - About trauma, you learn nothing about trauma in college, nothing. Emergency service is a field [...] that you have to deal with strong feelings well, control your feelings. In a moment, you have to act, without any time to think.

Nursing programs are still trying to adapt to current needs, according to social development that has occurred, though some aspects still need to be rethought and reformulated(6,11).

Nurse Hotel - There isn't supervised training for nursing students in the prehospital service. I think it is necessary because the emergency medical service is here to stay $[\ldots]$, SAMU is currently present in all Brazilian capitals and big cities.

The academic education of nurses is generalist and does not include the legal aspects required in EMS, the aspects of a nurse making her capable of facing challenges oftentimes greater than those experienced in intra-hospital practice ${ }^{(6,12)}$.

Nurse Golf - I'm an appraiser for an accreditation program and I think that academic education has to change. Requiring more from the students' posture in the face of patients [...] their posture is very inappropriate [...], they underestimate the patients' complaints [...] they refer to people in an unethical way. People leave college very raw, but we note that some people are better due to their posture [...], professionals cannot graduate so easily [...] I guess they have to suffer a bit more.

Nurses have sought ways to compensate for this gap and complement their education through courses and training programs such as Advanced Cardiac Life Support (ACLS), Advanced Trauma Life Support (ATLS), Prehospital Trauma Life Support (PHTLS) or even Basic Life /Support (BLS), but these were not considered sufficient to meet the real requirement of EMS due to the difficulties of adapting the real situations found in the service practice in the laboratory, such as difficult access to the site where the victims are or having to deliver care inside the ambulances ${ }^{(6,12)}$.

\section{Sixth category: "nurses' perceptions of the EMS"}

Nurses face many challenges and difficulties when they enter the EMS, but they have managed to master the practice and successfully delivered care, which is the main function of nursing.

Nurse Golf - It's really good to work with SAMU [...] it's where I feel satisfied [...] and I keep thinking that I'll have to leave it soon, but I can't see a place to work other than in the prehospital service. It's the place that most pleased me.

The motivation to work with dedication, love and efficiency derives from the satisfaction of working for SAMU and in the EMS, feelings that reflect the valorization and acknowledgement of their work.
Nurse Charlie - The nurse working in EMS is a "mega nurse", has to master the pathologies, techniques and protocols to be a good nurse.

The reports indicate that nurses working in EMS are unique professionals and have great technical ability, emotional balance and personal preparedness.

Nurse Hotel - it's scary at the beginning, but it's fascinating when you start getting involved with the EMS, you end up enthralled [...]. You end up learning how the whole care network functions.

The great mobility that's part of the EMS allows SAMU nurses to observe and evaluate the health situation in the city.

Nurse Bravo - I expect that nurses really assume this as an independent profession [...]. As you get knowledge, you became respected and start to like even more of what you do. Personally, I feel realized as a nurse.

Changes in relation to academic education are emerging, though with a certain delay, given the real needs observed in the services and the professional level of nurses who already work in EMS.

\section{Final considerations}

The feelings related to EMS and evidenced in this study characterize EMS as a service that demands professional ability, general and specific knowledge, mastering of techniques, pathologies, protocols, leadership, management and emotional balance. It is the place where the interviewed nurses found satisfaction, personal and professional realization, in addition to valorization and acknowledgement by patients/victims and their family members, population and the service itself.

Regarding the nurses' professional education, the study evidenced the need for training schools to demand from students an appropriate posture in relation to patients and the need to promote supervised training and observational opportunities for students in EMS during their undergraduate program.

A study carried out in São Paulo in 2008 with nurses working in EMS aiming to verify their opinion concerning the theoretical knowledge and nursing skills necessary to work in EMS reinforces the need to acquire specific skills and abilities, corroborating the importance of qualifications in the field(12).

This is evidenced again in this study carried out in Porto Alegre where the nurses report that preparedness to work in EMS is acquired inside SAMU and through courses, training programs and continuous learning in the service. None of the nurses in this study received 
specific training concerning EMS during their academic education, however, they consider previous intra-hospital experience important to work in their position.

In addition to specific attributes and responsibilities and everything that involves care delivery, EMS nurses also contribute to the planning, organization and managerial coordination of SAMU.

Positive experiences are considered relevant as they serve as stimuli to provide appropriate care in the service. Negative experiences, on the other hand, though they destabilize the teams, serve many times to bring understanding of the reality of some populations and motivate the work of sensitizing and educating people in the prevention of accidents and harm to health.

The biggest difficulties evidenced were related to entrance into the service, insufficient academic training, adversities of the situations, exposure to risk situations and a lack of psychological support.
EMS nurses have conquered and preserved their space through the search for new knowledge, posture and work they make reality. The gaps found in this study as well as the scarcity of studies addressing the theme that involves the practice and education of EMS nurses impede exhausting the subject and indicates the need for further studies in the form of literature reviews, reflection, experience reports and field research. It is important to stress that one cannot generalize this study's results to other professions due to its limitations, however, it is possible to affirm that these results reveal the context of this service in a Brazilian capital. This study should contribute to the scientific development of this specialty and enlarge the discussions about the professional practice and education of EMS nurses, enabling improvements in their work environment and promoting the development of a healthy practice.

\section{References}

1. Alcântara LM, Leite LJ, Erdman AL, Trevisan MA, Dantas CC. Enfermagem operativa: uma nova perspectiva para o cuidar em situações de "crash". Rev Latino-am Enfermagem. 2005 maio; 13(3):322-31.

2. Martins PS, Prado ML. Enfermagem e serviço de atendimento pré-hospitalar: descaminhos e perspectivas. Rev Bras Enfermagem. 2003 agosto; 56(1):71-5.

3. Ramos VO, Sanna MC. A inserção da enfermeira no atendimento pré-hospitalar: histórico e perspectivas atuais. Rev Bras Enfermagem. 2005 maio; 58(3):355-60.

4. Lopes SLB, Fernandes RJ. Uma breve revisão do atendimento médico pré-hospitalar. Rev Medicina (Ribeirão Preto) 1999 outubro-dezembro; (32):381-7.

5 Ministério da Saúde (BR). Portaria 2048, dispõe sobre o regulamento técnico dos sistemas estaduais de urgência e emergência. 2002. Diário Oficial da República Federativa do Brasil. Brasília: Imprensa Oficial; novembro 2002.

6. Vargas D. Atendimento pré-hospitalar: a formação específica do enfermeiro na área e as dificuldades no início da carreira. Rev
Paul Enferm 2006 março; 25(1):38-43.

7. Esperidião $E$, Munari DB. Holismo só na teoria: a trama de sentimentos do acadêmico de enfermagem sobre sua formação. Rev Esc Enferm USP 2004 setembro-dezembro; 38(3):332-40.

8. Bardin L. Análise de conteúdo. $7^{a}$ ed. Lisboa (Portugal): Edições 70; 1977.

9. Souza AIJ, Erdmann AL. Contribuições para o conhecimento em enfermagem à luz da fenomenologia da percepção de Merleau-Ponty. Rev Gaúch Enferm 2006 junho; 27(2):166-75.

10. Pereira WAP. Atendimento pré-hospitalar: caracterização das ocorrências de acidentes de trânsito. Acta Paul Enferm. 2006 maio; 19(3):279-83.

11. Malvestio, MAA, Sousa, RMC. Análise do valor predeterminante dos procedimentos da fase pré-hospitalar na sobrevivência das vítimas de trauma. Rev Latino-am Enfermagem 2008 maiojunho; 16(3):432-8.

12. Rosana CG, Ramos LH, Whitaker IY. Capacitação de enfermeiros em atendimento pré-hospitalar. Rev Latino-am Enfermagem. 2008 março-abril; 16(2):192-7.

Received: Mar. $23^{\text {rd }} 2009$

Accepted: Oct. $7^{\text {th }} 2009$ 